\title{
Leukokori er retinoblastom til det motsatte er bevist
}

\begin{abstract}
Retinoblastom er en sjelden diagnose, og tilstanden kan være svært vanskelig å oppdage. Rask henvisning til øyelege ved mistanke om leukokori er viktig, ikke minst fordi prognosen er god når sykdommen oppdages tidlig.
\end{abstract}

Publisert først på nett 21.9. 2012

Som lege og mamma ønsker jeg å skrive et innlegg med tanke på bevisstgjøring. Jeg hadde med mine tvillinggutter til tremånederskontroll på helsestasjonen. Ved undersøkelse av rød refleks hos den ene gutten, beskriver den erfarne helsestasjonslegen at hun mener hun ser sideforskjell. Det venstre øyet har et lysere, mer hvitaktig felt (leukokori), altså ikke god rød refleks over hele øyet. Tanken på retinoblastom slår meg. Legen mener imidlertid at det neppe er noen grunn til bekymring, og at dette bare skal kontrolleres. Retinoblastom er tross alt særdeles sjeldent, og mest sannsynlig dreier det seg om ekspansjon av papillen. Som bekymret mor, og samtidig lege med en del kunnskap om rød refleks, slår jeg meg ikke til ro med legens oppfatning av at dette er normalt. Jeg făr derfor med en henvisning til øyelege.

Det viser seg å være vanskelig å få tak i øyelege raskt, og jeg tar derfor med barnet til en barnelege på sykehus, for å få en ekstra vurdering (second opinion). Denne legen synes at rød refleks er sidelik, men anbefaler at det kontrolleres hos øyelege.

\section{Spesialistvurdering avgjørende}

Selv om jeg ble noe roligere til sinns etter dette besøket, fikk jeg ordnet med time hos øyelege samme dag likevel. Øyelegen er ikke i tvil, det er tydelig sideforskjell på øynene, med leukokori på det venstre. Vi blir derfor raskt sendt til øyepoliklinikken på sykehuset for videre undersøkelse. Her får vi den nedslående diagnosen: retinoblastom.

Med dette i tankene har jeg i ettertid sett igjennom bilder vi har tatt av barnet, og da kan man på noen av bildene se at det på høyre øye er fin rød refleks, mens det på venstre er mer hvit pupill (leukokori) (fig $1 \circ g$ 2). Det var allikevel også flere bilder med normal rød refleks bilateralt. Jeg kan ikke gjenfinne leukokori på bilder av tvillingbroren. For øvrig, som det er gjort et poeng av i en artikkel i The Lancet nylig (1), vil dagens fotokameraer ofte ha en funksjon for anti-rødøyne, som gjør det vanskeligere å oppdage leukokori på bilder.

Retinoblastom er en svært sjelden kreftform, som rammer ca. 1:14 000 barn, altså ca. fire barn per år i Norge (2). De vanligste debutsymptomene er leukokori og skjeling,

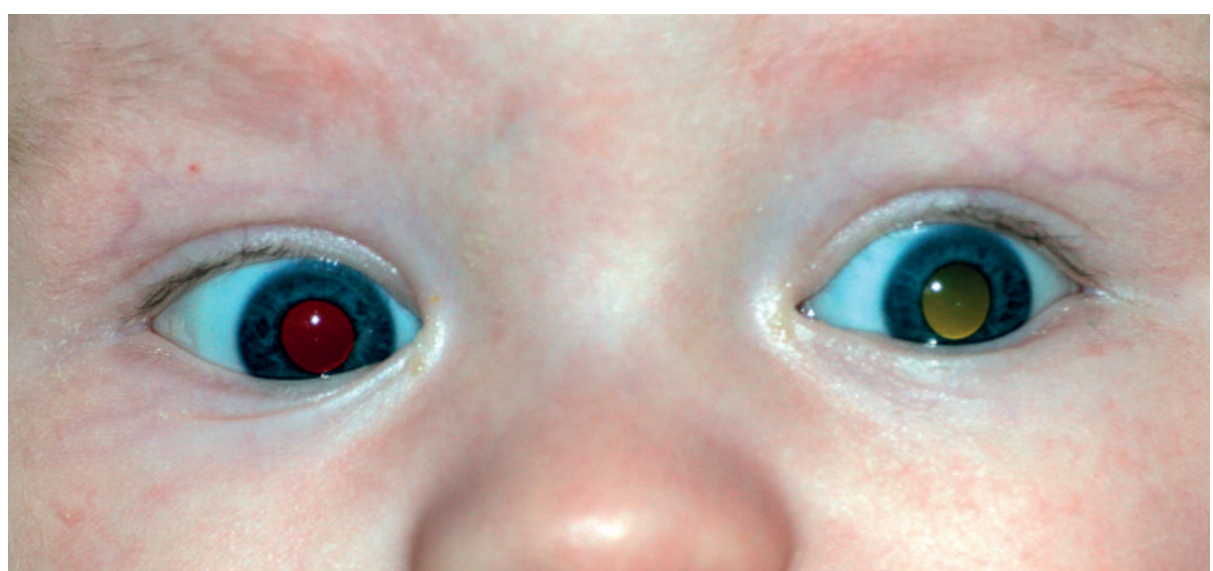

Figur 1 Leukokori på venstre øye

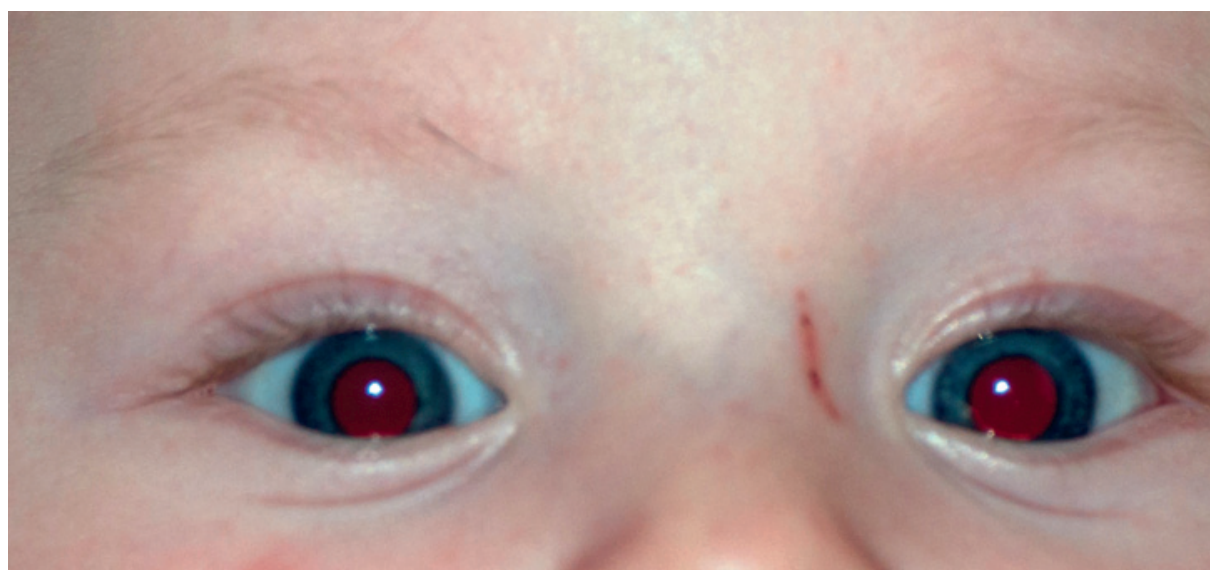

Figur 2 Normal rød refleks på begge øyne

og ved den minste mistanke om leukokori, skal barnet henvises til øyelege umiddelbart. Prognosen er god, over $95 \%$ overlevelse ved diagnostisering før toårsalderen (2).

Poenget mitt er at selv om diagnosen er sjelden og kan være svært vanskelig å fastslå, må man likevel ved minste mistanke om leukokori, henvise barnet til øyelege raskt!

\section{Stine Sandven-Thrane \\ stinewestby@gmail.com}

Pasientens far har gitt samtykke til at artikkelen blir publisert.
Stine Sandven-Thrane (f.1984) er lege i spesialisering i ortopedi ved Skadekirurgisk legevakt, Akershus universitetssykehus. Forfatter har fylt ut ICMJE-skjemaet og oppgir ingen interessekonflikter.

\section{Litteratur}

1. Murphy D, Bishop H, Edgar A. Leukocoria and retinoblastoma - pitfalls of the digital age? Lancet 2012; 379: 2465.

2. Kinge B, Tranheim RS, Eide NA. Retinoblastom arvelig øyekreft hos barn. Tidsskr Nor Lægeforen 2004; 124: 183-5.

Mottatt 16.8. 2012 og godkjent 6.9. 2012. Medisinsk redaktør Merete Kile Holtermann. 